\title{
RELIGIOSITY AND DEVOTION IN EDUCATIONAL ACTIONS
}

Nicolae Bolea*

Abstract: The material has been structured following these aspects:

Preliminaries - a general presentation of religious education in Romania and an emphasis on didactic imperatives nowadays.

I. Secular educators involved in religious education; emphasis on their support and involvement.

II. Religion in the postmodern world; an attempt to approach some of the avalanches of challenges addressed to the Christian Church and to religious education.

III. The Church and education also represent an attempt to analyse society and the effort of the Church facing a society growingly influenced by the phenomenon of secularism.

$I V$. This is what God established for us - a plea for the Romanian people, born Christian and the struggle to survive under the protection of the Church through the effort of religious education.

Keywords: education, religion, school, christian, Church.

\section{Preliminarii}

În centrul învăţământului religios este nevoie de creare a unui climat bazat pe valori, astfel încât actul educativ să devină o mărturie vie a apostolatului în folosul semenilor. În ciuda pluralismului cultural, demnitatea şi unicitatea fiecărei persoane trebuie să se regăsească în miezul proiectului educaţional inspirat de valorile Evangheliei. Se prezintă aşadar provocarea de a deveni ora de religie primitoare şi fraternă, unde fiecare să se simtă binevenit, acceptat şi respectat, unde nimeni să nu ajungă marginalizat sau exclus, iar ora de religie să-i contamineze pe toţi, în sensul nobil al cuvântului - în

\footnotetext{
* PhD, Teacher at the „St. Simion Ştefan” Orthodox Theological Seminary, Alba Iulia, Romania; School Inspector for Religion at the Alba County School Inspectorate.
} 
egală măsură pe cei dinăuntru şi pe cei dinafară - de această bunătate şi fraternitate, generând astfel pace, dreptate, milă şi caritate.

Valorile creştine, care s-ar cuveni să fie prezente şi respectate în societatea românească şi cu atât mai mult în şcoala românească, trebuie să se determine în abordarea unui mod de cunoaştere deschis transcendenţei. Este vital ca profesorii de religie să-şi păstreze intacte speranţa şi curajul de a fi mărturisitori ai valorilor Evangheliei, ca rezultat direct al unei pasiuni mereu reînnoite pentru Hristos şi pentru educaţie. Dincolo de necesitatea unei investiţii în competenţe, accentul trebuie pus pe calităţile umane, astfel încât învăţarea să nu se limiteze la o simplă asimilare de conţinut infomaţional, ci să ofere accesul la dimensiunea spirituală a existenţei.

Pe fondul acestei abordări, apreciem că-n societatea contemporană, Biserica şi implicit educaţia religioasă a generaţiei tinere este chemată la cântărirea unor realităţi şi urmare, la încercarea de-a găsi soluţiile cele mai potrivite. E nevoie de curaj în abordare, dar şi de un spirit al obiectivităţii şi realităţii sociale. Să părăsim ceea ce înseamnă confort personal, să luptăm pentru eradicarea dezordinii morale, să încurajăm tinerii pe care-i formăm că un suflet care-L urmează pe Hristos va fi fericit şi nu va cunoaşte boala, depresia, tristeţea. Indiferent dacă şcoala se află într-o urbe impunătoare sau într-un sat neînsemnat, profesorii de religie sunt chemaţi să semene în inimile elevilor germenii păcii, ai dreptăţii şi ai milostivirii, ai iertării şi ai speranţei.

Se cuvine să fie în atenţie şi zona de periferie a socialului. Trebuie să fie căutaţi şi cei săraci şi cei nevoiaşi. Aceşti copii, oneşti tineri din aceste zone şi cu asemenea situaţii au ceva ce copiii şi tinerii din zonele mai bogate nu au - nu din vina lor, ci pentru că este o realitate sociologică: ei au experienţa supravieţuirii, dar şi a cruzimii, a foamei, a nedreptăţilor. Ei au o umanitate rănită. Noi credem şi mărturisim că mântuirea vine din rănile OMULUI DUMNEZEU rănit pe Sfânta Cruce. Din aceste răni, ei, copiii şi tinerii, extrag înţelepciune în cazul în care un profesor de religie îi călăuzeşte. 
Este observabil în rândul generaţiei tinere că tot mai mult, mai evident, se conturează ca mijloc de comunicare trei limbaje: limbajul capului, limbajul inimii, limbajul mâinilor. Educaţia religioasă nu trebuie să ocolească acest contur şi trebuie să facă efortul de-a se adopta în a se desfăşura şi pe aceste trei direcţii ${ }^{1}$.

În contextul Deciziei nr. 669 din 12 noiembrie 2014 a Curţii Constituţionale a României, al înscrierii elevilor pentru ora de religie, al procesului legislativ din Parlament, corelativ deciziei Curţii Constituţionale, al dezbaterilor referitoare la educaţia religioasă în şcoli, s-au constatat importanţa şi necesitatea intensificării cooperării dintre Familie, Şcoală şi Biserică în domeniul educaţiei, în general, şi al educaţiei religioase, în $\bmod$ special, cu valorificarea responsabilităţii specifice ale acestor trei instituţii majore. Părinţii au înţeles necesitatea intensificării cooperării dintre Familie, Şcoală şi Biserică, astfel încât educaţia religioasă primită acasă să fie susţinută în mod complementar prin educaţia copiilor şi a tinerilor în viaţa Bisericii şi a Şcolii. În această perspectivă, poate fi valorificat şi materializat cadrul oferit de parteneriatul dintre parohie şi şcoală. Scopul parteneriatului este ajutorarea elevilor din familii defavorizate, dar şi colaborarea pentru îmbunătăţirea orei de religie, precum şi a desfăşurării de activităţi extraşcolare şi extracurriculare comune.

Preafericitul Părinte Patriarh Daniel la Simpozionul Naţional de Pedagogie Creştină „Repere ale educaţiei creştine în teologia Sfântului Ioan Gură de Aur, actualizate în relaţia Biserică - Familie Şcoală din contextul contemporan" desfăşurat în perioada 28-29 aprilie 2015 la Centrul Naţional pentru formare continuă „Dumitru Stăniloae" din Bucureşti a evidenţiat câteva aspecte fundamentale corelându-le cu cele trei secţiuni tematice ale simpozionului:

1. Rolul educațional al familiei, asumat şi valorificat în contextul ideologic al societăţii contemporane;

${ }^{1}$ Mioriţa Got, Educaţia - o pasiune care se reînnoieşte, în „Viaţa creştină”, Cluj Napoca, anul XXVII, nr. 3 (445), 2016, p. 19-21. 
2. Importanţa, actualitatea şi relevanţa educaţiei religioase $\hat{\imath} n$ şcoală pentru societatea contemporană;

3. Educaţia - realitate constantă şi dinamică în viaţa şi misiunea Bisericii.

Valoarea educaţiei, atât în Familie, cât şi în Biserică şi în Şcoală, are o relevanţă pentru istorie, şi chiar pentru veşnicie, în măsura în care ea este cultivată cu deschidere spre dobândirea vieţii şi fericirii veşnice în iubirea eternă a lui Dumnezeu. În contextul actual, al unei societăţi informaţionale şi tehnologizate excesiv, exista riscul ca educaţia să fie la un proces în care accentul cade aproape exclusiv pe achiziţionarea de informaţii performante, necesare pentru dobândirea unor competenţe şi abilităţi, astfel încât tânărul să fie integrat facil şi sigur într-un sistem de eficienţă practică imediată, dar tot mai impersonal.

Tocmai într-o asemenea situaţie este relevantă valorificarea specificului formativ al educaţiei religioase şi mărturisirea faptului că o educaţie creştină nu poate fi structurată într-un orizont limitat şi efemer, ci în lumina iubirii eterne a lui Hristos, „Care ieri, astăzi şi in veci acelaşi" (Evr. 13, 8). În acest sens, Sfântul Ioan Gură de Aur îndeamnă, zicând:

„Nu voi înceta îndemnându-vă, rugându-vă şi căzându-vă înainte, ca mai întâi de toate celelalte să vă puneţi în bună rânduială copiii ... Creşte un atlet pentru Hristos, învaţă-1 evlavia din fragedă vârstă ... Să sădim şi să antrenăm în copil înţelepciunea, ca să cunoască lucrurile omeneşti, ce este bogăţia, slava, puterea, ca să le dispreţuiască şi să dorească (virtuţile) cele mari. Să-i aducem aminte cuvintele de îndemn: 'Copile, numai de Dumnezeu să te temi şi afară de El să nu te temi de altcineva'. Frica de Dumnezeu e de ajuns pentru înţelepciune şi pentru a avea în lucrurile omeneşti judecata pe care se cuvine să o avem. Căci culmea înţelepciunii aceasta este: a nu fi pasionat de cele copilăreşti. Să fie educat să socotească drept nimic banii, drept nimic slava omenească, drept nimic puterea, drept nimic moartea. Şi aşa va fi înţelept" ${ }^{\prime 2}$.

2 Sfântul Ioan Gură de Aur, Cuvânt despre educaţia copiilor, Sibiu, Edit. Deisis, 2006, p. 136-137, 171, apud Daniel, Patriarhul Bisericii Ortodoxe Române, Lumina educaţiei promovată în cooperarea dintre Biserică, Familie şi 


\section{Pedagogi laici ortodocși în sprijinul educației religioase}

Într-o abordare teologică asupra demersului despre izvoarele predicii, ale catehezei şi ale învăţământului religios, în general, se jalonează punctele de referinţă: Sfânta Scriptură, Sfânta Tradiţie (îndeosebi Sfinţii Părinţi) la care se adaugă scrieri ale ierarhilor, preoţilor şi profesorilor de teologie. De multe ori, intelectualii laici, din trecut şi de astăzi, nu puţin la număr, au fost ocoliţi, deşi s-au remarcat în alte domenii decât teologia, dar s-au dovedit buni ortodocşi, cu multă râvnă în efortul de luminare creştină a tinerelor generaţii. Nominalizăm doar o parte din cei care au ostenit şi dăruit Bisericii şi culturii româneşti ofranda şi osteneala lor atâtor generaţii: Dionisie Făgărăşanu, Simion Mehedinţi, G. G. Antonescu, Onisifor Ghibu, Nichifor Crainic, Nae Ionescu, Teodor M. Popescu, Ştefan Bârsănescu, Constantin Narly, Vasile Băncilă, Ion Găvănescu, Mircea Vulcănescu, Nicolae Paulescu, Vasile Voiculescu, Petre Țuţea, Ernest Bernea, Constantin Noica, Virgil Cândea, Daniel Turcea, Ioan Alexandru, Constantin Cucoş, etc ${ }^{3}$.

Facem doar o sumară referire la Nichifor Crainic, pe care una dintre enciclopedii îl numeşte scriitor, poet, ziarist, om politic, autor, director de reviste, editor, filisof (creator al curentului gândirist), pedagog şi teolog român ${ }^{4}$.

În criza spiritualitate românească de după primul război mondial, alături de alţi corifei remarcabili, în spaţiul cultural românesc apare figura luminoasă a lui Nichifor Crainic. El se înscrie vertiginos pe lista personalităţilor culturale ${ }^{5}$ care au declanşat

Şcoală, în „Vestitorul Ortodoxiei”, anul VIII (XXV), nr. 5-6 (503- 504), maiiunie, 2015, p. 18-19.

${ }^{3}$ Vasile Gordon, Nichifor Crainic - nume de cinste pentru o,, Antologie românească a pedagogilor laici ortodocşi, în „Tabor”, anul III, nr. 10, ianuarie, 2010, p. 40-41.

${ }^{4}$ Metapedia. A se vedea http://www. ro.metapedia.org/wiki/Nichifor_Crainic (accesat la data de 15. 07. 2009).

${ }^{5}$ Vasile Gordon, op. cit., p. 41. Într-un elogiu adus lui Nichifor Crainic, Lucian Blaga recunoaşte existenţa în opera acestuia a tradiţiei gândirii patristice 
dezbaterea asupra rolului Ortodoxiei în viaţa socială; printre marii dascăli care au înţeles ce este chemarea apostolică. Înnoirea creştină a lumii trebuie de la copii. Se ştie despre Nichifor Crainic că a urmărit cu tenacitate şi consecvenţă încreştinarea vieţii publice româneşti, fiind un neobosit animator cultural şi un veritabil îndrumător religios. Important pentru învăţământul religios românesc este principiul înnoirii lumii prin copil, principiul oricărei pedagogii realiste. El vede scopul educaţiei creştine trecând dincolo de marginile vieţii pământeşti şi are în vedere chemarea omului în veşnicie. De aceea, militează pentru o educaţie creştină ortodoxă, care se desăvârşeşte prin Biserică, îndemnând la o reală creştinare a statului şi în cadrul Bisericii, şi atenţionează clar că aceasta este rânduiala lumii de la Hristos încoace ${ }^{6}$.

\section{Religia în lumea postmodernă}

Într-o viziune retrospectivă, în zorii creştinismului, când Apostolii au pornit din Palestina pentru a propovădui Evanghelia lui Hristos s-au confruntat nu numai cu o lume care se folosea de o limbă diferită, greaca, dar şi care avea mentalităţi şi concepte filosofice diferite. Primii parteneri de dialog ai părinţilor Bisericii îi vom găsi nu în templele păgâne, ci în şcolile filosofice greceşti. Spre deosebire de pescarii ignoraţi din Galileea, oamenii de cultura din lumea mediteraneană, convertiţi la creştinism, au încercat să apere noua credinţă de criticile venite din partea cărturarilor şi filosofilor necreştini, dar şi să-şi perfecţioneze ideile. Aceşti învăţ̧aţi, numiţi mai târziu apologeţi, nu au ezitat să caute adevărul în filosofia greacă

răsăritene. De asemenea, atunci când Nichifor Crainic devine membru al Academiei Române, tot Blaga va spune: „El nu vine singur intre noi. $\mathrm{Cu}$ el alături intră în Academia Română şi Dionisie Areopagitul, Maxim Confesorul şi Ioan Damaschin (...)" cf. Nichifor Crainic, Zile albe, zile negre”, ediție îngrijită de Nedic Lemnaru, Bucureşti, Casa Editorială „Gândirea”, 1991, Notă asupra editiei, p. XVI.

${ }^{6}$ Ibidem. 
şi să-i adapteze noţiunile pentru a veni în ajutorul aserţiunilor din adevărul creştin? .

Europa medievală a dezvoltat în interiorul său trei mari instituţii: sacerdotium (biserica), imperium (statul) şi studium (universitatea). Multe din rivalităţile care au existat între ele s-au dezvoltat în revendicările provocate de conflictele dintre sacerdotium si imperium, amândouă susţinându-şi prerogative prin afirmaţii autobiografice cu privire la „semnificaţiile lor”. Pe de altă parte, studium a încercat permanent să menţină un echilibru între cele două semnificaţii ale lui ,interior" şi „exterior", fiind astfel prins între cele două puternice instituţii.

Europenii din epoca modernă, care au făcut experienţa Renaşterii şi a Iluminismului, s-au considerat creatori ai noilor valori culturale şi purtători ai unei civilizaţii autentice, care era de facto o pseudo - religie de mântuire, secularizată. Această concepţie constituia suportul ideologic, atât al Revoluţiei industriale, cât şi al Revoluției franceze, fiind forţa care motiva expansiunea colonială a naţiunilor europene moderne ${ }^{8}$.

Secularizarea poate fi definită ca fiind procesul de schimbare a orientării cu privire la fundamentarea religioasă a gândirii şi acţiunii, cu una centrată pe lume, ca singura realitate perceptibilă. Termenul de secularizare a fost folosit pentru prima dată cu referire la Pacea de la Westphalia (1648), care a dus, printe altele, la un transfer al proprietăţilor bisericii în mâinile prinţului. Sociologii sunt de părere că secularizarea este caracterizată de trei aspecte: (1) o descreştere a religiozităţii, (2) o restrângere a semnificaţiei religiei şi (3) o secularizare internă - adaptarea religiei la ideile modernitaţii. Este important să facem distincţie între iluminism, care trebuie perceput ca o mişcare a celor puţini, cu alte cuvinte adică un fenomen elitist, şi secularizare, care este o mişcare a celor mulţi, adică un fenomen de masă. De asemenea, este greşit să ne imaginăm

\footnotetext{
${ }^{7}$ Mircea Gelu Buta, Religie şi universitate în postmodernism, în „,Tabor”, anul IV, nr. 4, iulie, 2010, p. 68.

${ }^{8}$ Ibidem, p. 69-71.
} 
că înainte de secolul al XIX-lea societatea a fost eminamente religioasă, iar după această perioadă, ea şi-ar fi pierdut această componentă ${ }^{9}$.

Marxismul şi comunismul au devenit agenţii cei mai eficienţi ai secularizării în ultimele două secole. Acestea reprezintă prin durata cronologică, întinderea geografică, brutalitatea metodelor şi numărul mare al victimelor un capitol de istorie pe care cu greu îl putem ignora, a cărui tragică importanţă va rămâne probabil şi după două secole de acum înainte. Această realitate îl determină pe Václav Havel, într-un interviu din 2007 despre Charta 77, să vadă postcomunismul ultimelor două decenii drept ecoul nedisimulat al comunismului ca atare ${ }^{10}$. Una peste alta, invers proporţional cu amploarea mediatică şi speranţele puse în schimbarea paradigmei politice căderii comunismului nu i-a urmat practic nicio etapă sistematică de sintetizare şi evaluare.

${ }^{9}$ Ibidem, p. 71-72
${ }_{10}$ Radu Preda, Condamnarea comunismului. Dilema etică a Europei, în „Tabor”, anul III, nr. 7, octombrie, 2009, p. 60. Pentru o încadrare generală a comunismului în istoria ideilor politice vezi sinteza de referinţă semnată de Chantal Millon-Delson, Les Idées politiques au XX ème siècles, Presses Universitaires de France, Paris, 1991, în româneşte: Ideile politice ale secolului $X X$, trad. V. Boari, Iaşi, Edit. Polirom, 2002. Pentru o analiză aprofundată a mecanismelor ideologice ale comunismului vezi clasicul în materie, François Furet, Le Passé d'une illusion. Essair sur l'idée communiste au XX-e siècle, Robert Laffont/ Calmann-Lévy (eds.), Paris, 1995, în româneşte: Trecutul unei iluzii. Eseu despre ideea comunistă în secolul XX, trad. E. Marcu, V. Russo, Bucureşti, Edit. Humanitas, 1996. O foarte bine scrisă istorie succintă a comunismului oferă şi Richard Pipes, Communism. A Brief History, London, Weidenfeld \& Nicholson, 2001.

Acordat iniţial publicaţiei franceze Le monde, interviul cu Havel poate fi găsit pe pagina de internet a Ministerului de Externe de la Praga, http://www.czech.cz/de/publizistik/vorstellung-der-tschechischenrepublik/vaclav-havel-wir-stehen-am-beginn-schwerwiegender-veranderungen, (accesat la data de 15. 07. 2009). 


\section{Biserica și educația}

\section{1 Biserica şi cultura}

A vorbi despre Biserică şi cultură, nu este oare o încercare de a pune de acord două realităţi diferite, ba chiar opuse ? Tocmai sub acest aspect de contrast şi de conflict le-a privit şi le priveşte încă multă lume. Într-adevăr, pentru mulţi, printre care se numără, atât credincioşii, cât şi necredincioşii - unii istorici, filosofi, sociologi şi mai ales ideologi ai socialismului şi comunismului - Biserica este o instituţie obscurantistă, reacţionară, inamică a progresului şi a culturii. Alţii, din diverse motive, cred că Biserica nu are nimic de câştigat dintr-o alianţă cu cultura acestei lumi, ci că trebuie să se îndepărteze de aceasta, spre binele său. Sunt, însă, mulţi care consideră că, dimpotrivă Biserica şi cultura se pot înţelege şi pot colabora, altfel spus, că Biserica poate şi trebuie să se ocupe de cultură.

Problema care se pune în această vreme în care trăim este tocmai de a releva drepturile Bisericii asupra culturii şi de a o pune în situaţia de a-şi îndeplini cât mai bine datoria pe care o are faţă de aceasta, pentru a asigura din nou culturii şi umanităţii asistenţa binefăcătoare şi mântuitoare a creştinismului. Ce poate aduce Biserica în acest scop lumii moderne ? Ceea ce le-a adus întotdeauna: forţa morală a religiei, legea mântuitoare a lui Hristos, spiritul şi virtuţile Evangheliei, moravurile şi instituţiile creştine, fără care nu se poate edifica pentru societate o casă solidă şi sigură: ideea autorităţii divine, ierarhia valorilor, simţul moral, un ideal care depăşeşte contingentul ${ }^{11}$. Desigur, Biserica nu este solidară cu orice preţ cu cultura. Nu-şi poate lega soarta de cea a culturii, ea se află şi trebuie să rămână întotdeauna mai presus de cultură, o instituţie supranaturală, întrucât este mai presus de fire. Alianţa sa cu cultura este condiţionată şi limitată, nu merge până la capăt, ci se opreşte

${ }^{11}$ Teodor M. Popescu, Biserica şi cultura, Bucureşti, Edit. Institutului Biblic şi de Misiune al Bisericii Ortodoxe Române, 1996, p. 214-224 
acolo unde conştiinţa Bisericii de Trup al lui Hristos îi cere să se oprească. Cultura poate rătăci, poate decădea, se poate chiar compromite $^{12}$.

\section{2. Educaţie şi religie}

Multă se întreabă dacă educaţia are nevoie de religie. Răspunsul nu poate fi decât afirmativ. Da, educaţia are nevoie de religie pentru variatele contribuţii în iniţierea culturală, în formarea personalităţii şi în orientarea spre binele comun, care, iată, toate decurg din religie. Desigur, educaţia necesită în primul rând o deschidere de principiu faţă de religie, pentru a putea corespunde cu ceea ce omul este în experienţa sa cea mai profundă, adică o fiinţă care abia prin întrebarea despre relaţia cu sine însăşi, cu lumea şi cu Dumnezeu, pătrunde în propria sa taină. A neglija orice latură a acestei mişcări decăutare ar însemna pierderea din vedere a uneia dintre rădăcinile fiinţei umane. Statului însuşi, neutru din punct de vedere al concepţiei despre lume, nu-i este indicată eliminarea religiei din sistemul său educaţional, sub pretextul asigurării sferei de independenţă a cetăţenilor săi, ci preluarea religiei în acest proces ${ }^{13}$.

Invers, are nevoie religia de educaţie ? Răspunsul este din nou afirmativ. Da. Credinţa creştină, în esenţa ei profundă, un act cuprinzător de încredere personală, însă definit din puncte de vedere al conţinutului şi, prin aceasta, raportat la realitate, în care raţiunea este suprasolicitată. $\mathrm{O}$ credință care nu dă socoteală de ,nădejdea noastră, care ne umple" (II Cor. 1, 3-7) nu ar fi biblică şi umană ! În acelaşi timp, credinţa creştină este orientată în mod esenţial spre configurarea lumii, care la rândul ei se defineşte într-un sens foarte cuprinzător prin educaţie, ca premiză indinspensabilă a eficienţei şi afectivităţii. Astfel, relaţia dintre educaţie şi religie poate fi desemnată, în principiu, drept una a dialogului ${ }^{14}$.

\footnotetext{
${ }^{12}$ Ibidem, p. 225.

${ }^{13}$ Mircea Gelu Buta, op. cit., p. 74.

${ }^{14}$ Christoph von Schonborn, în Andrei Marga, Dialoguri, Cluj-Napoca, Presa Universitară Clujeană, 2008, p. 189, apud Mircea Gelu Buta, op. cit., p. 74.
} 
Realitatea ne demonstrează că interesul pentru valorile creştine în universităţile europene este cu mult mai mare decât înainte. Aceasta se datorează faptului că realizările ştiinţei şi tehnicii pot fi utilizate în scopuri bune, dar şi rele. Unele descoperiri fundamentale din domeniul ştiinţei au fost folosite în războaie, în acţiuni teroriste sau de injustiţie. Aceasta ne determină să ne gândim cum putem forma fiinţa umană, adică responsabilizarea ei în utilizarea ştiinţei şi tehnicii pentru binele umanităţii. Poate acest interes este mai pregnant în ţările postcomuniste, unde în vremea regimului comunist nu exista libertate, ci doar ateism, care nu permitea cultivarea valorilor creştine în universitate sau în viaţa publică. Iată că acum majoritatea universităţilor au dorit să înfiinţeze facultăţi de teologie ${ }^{15}$. Europa are rădăcini creştine, fapt care nu se poate nega şi care se exprimă mereu prin manifestări culturale. A tăia ceste rădăcini ar însemna să avem o Europă fără identitate, care nu ar putea niciodată să se proiecteze în mod autentic în viitor. A renega, din cauza unor prejudecăţi ideologice, propriile rădăcini înseamnă, până la urmă, să-i faci rău Europei, pentru că ar însemna ca fiecare ţară să renunţe la rădăcinile sale culturale. Acest lucru este inadmisibil într-o Europă Unită, deoarece în Europa Unită fiecare ţară, fiecare naţiune trebuie să-ţi apere identitatea. Uniunea sau globalizarea nu trebuie să piardă din vedere unicitatea, valoarea persoanei, deci şi valorile tradiţiilor cultural-istorice ale fiecărei ţări ${ }^{16}$.

Dacă în cazul educaţiei, idealul se poate modifica în funcţie de tendinţele de evoluţie a societăţii, idealul creştinismului se află în directă relaţie cu scopul creării omului, fiind formulat la modul absolut de către Fiul lui Dumnezeu întrupat: cunoaşterea şi iubirea lui Dumnezeu. Înţelegerea scopului pentru care a fost creat omul şi acceptarea revelaţiei divine ${ }^{17}$ reprezintă fundamente pentru formarea

\footnotetext{
${ }^{15}$ Ibidem.

${ }^{16}$ Ibidem, p. 272, apud Mircea Gelu Buta, op. cit. p. 74-75.

17 Revelaţia reprezintă descoperirea de către Sine a lui Dumnezeu şi cunoaşterea Lui de către oameni, fără de care aceştia nu ar avea posibilitatea să cunoască adevărurile divine, voia şi lucrarea Lui şi nu ar intra în comuniune de
} 
convingerii privind posibilitatea atingerii idealului creştin prin educaţie.

Afirmaţia potrivit căreia idealul educaţiei religioase se află în relaţie cu scopul creării omului îşi găseşte suportul în înţelegerea faptului că devenirea fiinţei umane, creşterea spre asemănarea cu Dumnezeu, participarea la bunătăţile dumnezeieşti sunt posibile numai în comuniune cu Dumnezeu, înţeleasă într-o dinamică, în care rolul educaţiei este hotărâtor ${ }^{18}$.

Complexitatea fenomenului educaţional religios, nevoia de ancorare permanentă la realităţile din sfera religiosului, dar şi de adaptare la schimbările din societate, necesitatea optimizării permanente a activităţii educative pe toate componentele şi subcomponentele acesteia ridică o serie de întrebări al căror răspuns poate fi dat doar pe baza rezultatelor cercetărilor pedagogice ${ }^{19}$. Creştinismul presupune şi un important fapt cultural, care a contribuit în mod decisiv la perfecţionarea formelor de exprimare a credinţei în locuri şi perioade cu particularităţi dintre cele mai diferite, motiv pentru care contribuţia care a adus-o la răspândirea învăţăturii revelate nu poate fi desprinsă de sfera educaţiei. Un sistem educativ care se limitează la o simplă transmitere a unui set de valori şi la perpetuarea unei experienţe acumulate până la un moment dat este incomplet şi efemer. Sistemul educativ contribuie în mod decisiv la articulare unui mecanism capabil să actualizeze şi să recreeze condiţiile acceptării valorilor culturale transmise, în cosonanţă cu posibilităţile de receptare aflate în continuă schimbare. Se dovedeşte, astfel, că religia noastră nu poate fi încadrată în categoria

iubire cu El. Cf. Ene Branişte, Ecaterina Branişte, Dicţionar enciclopedic de cunoştinţe religioase, Caransebeş, Edit. Dicezană, 2001, p. 410, apud Dorin Opriş, Monica Opriş, Religia şi educaţia de mâine. Cercetări pedagogice, ClujNapoca, Editura Eikon, 2013, p. 252.

${ }^{18}$ Dorin Opriş, Monica Opriş, op. cit., p. 252-253

${ }^{19}$ Ibidem, p. 17 
ideologiilor, fiind un sistem religios şi educativ complex, marcat de spiritualitatea pe care o propune $\mathrm{e}^{20}$.

\section{Așa ne-a lăsat Dumnezeu}

\section{1. Înrădăcinarea în spațiul propriu}

Peste teritoriul poporului român au trecu multe popoare. Poporul român nu li s-a opus când ele treceau fără a căuta să pună stăpânire pe teritoriul lui dintr-un neastâmpăr de deplasare, deci când treceau în întregime, fără intenţii pan imperialiste. Acestea până la urmă s-au întors în Orientul de unde au plecat sau şi-au găsit un nou spaţiu, printre alte popoare, şi s-au asimilat culturii occidentale. Poporul român a permis, de asemenea, altor populaţii să se infiltreze în anumite părţi ale teritoriului său , când nu faceau aceasta cu intenţia de a-l scoate pe el din acest teritoriu sau nu ameninţau existenţa lui. Când observa că unele populaţii erau aşezate pe teritoriul său de forţe statele vecine sau vremelnic stăpânitoare din punct de vedere politic a vreunei părţi din teritoriul său, cu un plande cucerire treptată a acestui teritoriu, îşi lua măsuri de apărare.

Poporul român însuşi nu şi-a părăsit niciodată teritoriul său. El n-a putut face aceasta în primul rând pentru că aici s-a pomenit din vremea formării sale lingvistice şi spirituale. Spaţiul pe care-1 locuieşte s-a imprimat în fiinţa lui. El nu poartă urmele memoriei nici unui alt spaţiu. El îi consideră pe membrii oricărei alte populaţii ce trece pe aici sau se infiltrează aici ca străini nu numai faţă de sine, ci şi faţă de locul acesta, pe când ei sunt de aici. Când încep însăşi sa-şi aroge însă dreptul de stăpâni, atunci îi eticheteaza cu un cuvânt prin care vrea să arate că le contestă acest drept: venetici.

El caracterizează legătura mai puţin adâncă a celor ce au venit de altundeva pe acest teritoriu şi legătura de neclintit cu el, prin zicala apa trece, pietrele rămân. Mihai Eminescu a exprimat înrădăcinarea

${ }^{20}$ Dorin Opriş, Dimensiuni creştine ale pedagogiei moderne, ediţia a III-a, Bucureşti, Edit. Didactică şi pedagogică R. A., 2012, p. 24. 
poporului român în spaţiul său prin versurile nemuritoare: Dar noi locul ne ţinem, cum am fost aşa rămânem.

Ba se poate spune că în aceste versuri este exprimată nu numai înrădăcinarea poporului român în spaţiul său, pentru că vieţuieşte în el din vremuri imemoriale, ci şi un al doilea motiv al acestei înrădăcinări: persistenţa poporului nostru în acest spaţiu corespunde unui anumit mod de a fi al lui ${ }^{21}$.

\section{2. Îmbinarea caracterului latin cu creștinismul ortodox}

Caracterul nostru latin nu este străin de vechimea fiinţei noastre de traci, care nu s-au mutat niciodată din acest spaţiu de mijloc între Occident şi Orient şi primind şi creştinismul originar oriental, a întărit caracterul de sinteză al spiritualităţii poporului român.

Noi nu suntem unilateral raţionalişti ca latinii din Occident sau ca grecii, care au influenţat latinitatea occientală, nici unilateral mistici ca slavii sau ca popoarele asiatice şi africane - de un panteism şi mai total religiile lor impersonaliste - ci unim luciditatea raţională a latinităţii personaliste cu sentimentul de taină prezentă în toate, dar cu o taină luminoasă, în care se poate înainta la nesfârşit şi care nu ne anulează ca persoane originare în sentimentul unităţii de comuniune pe care îl trăim. Trăiera tainei de către poporulnostru, de luciditate luminoasă latin, a pus o pecete de adâncire şi de graţie pe cuvintele noastre latine. Noi am transformat convenţia, oarecum juridică, în cuviinţă de o delicatețe intraductibilă. Am transformat dolorul latin al durerii simple, în dorul în care durerea capătă dimensiuni vecinice şi intraducibile ${ }^{22}$.

21 Dumitru Stăniloae, Reflecţii despre spiritualitatea poporului român, Bucureşti, Edit. Elion, 2002, p. 5-6

${ }^{22}$ Ibidem, p. 16-17 


\section{Concluzii}

În limba românească de odinioară se spunea foarte des despre cineva: Aşa l-a lăsat Dumnezeu. Poate că nu suna atât de european ca unele expresii de astăzi, când am înlocuit plasticitatea unică şi bogăţia de nuanţe cu stereotipii monotone, sărace în sensuri, sunând ca nişte motoare stricate, pe punctul de a-şi da duhul. Aşa l-a lăsat Dumnezeu oglindea un adevăr de necontestat, o realitate şi un mister al creaţiei, propriu omenirii şi numai ei. Pentru că atunci când cuvintele nu mai sunt de ajuns ca să exprimăm ceea ce poate realiza un om, nu avem încotro şi trebuie să recunoaştem că el este dăruit de o Putere dincolo de măruntele noastre modalităţi de exprimare, de înţelegere, de receptare chiar. Şi atuncitoată aroganţa cu care ne îmbătăm, considerând că am spus tot ce se putea spune, că am mers până la limitele posibile ale inteligenţei şi gândirii, se topeşte, ca un fulg de zăpadă, strâns în palmă. Că nu ne putem înscrie ca o simplă etapă cantitativă a evoluţiei, la extremitatea superioară a scării fiinţelor vii, potrivit acelui nefericit adagiu cu care am fost îndopaţi şi îndoctrinaţi zeci de ani acumulări cantitative duc la salturi calitative, inscripţia de bază pe frontonul bibliei materialiste. Care ni se serveşte şi acum, într-o formă mai subtilă, bine-nţeles, mai ademenitoare, mai măgulitoare pentru ceea ce credem noi că este capacitatea noastră de a înţelege realitatea ${ }^{23}$.

$\mathrm{Cu}$ prilejul sărbătorii de la 1 Decembrie am auzit la televiziune mici interviuri cu oameni de pe stradă. M-au impresionat cuvintele unui puşti de vreo zece ani, care se învăluise într-un steag tricolor. Îl port pentru că sunt român, a spus el pentru că e steagul nostru. $\mathrm{N}$-am auzit niciodată vreun european vorbind dispreţuitor despre steagul ţării lui. Nemţii sunt convinşi că nicăieri nu există cultură ca a lor, arhitectură ca a lor, mod de viaţă ca al lor, muzică, literatură etc. Francezii vorbesc despre mândria lor de-a face parte din la grande nation. Nimeni nu-i priveşte batjocoritor! Spaniolii se

${ }^{23}$ Lidia Stăniloae, Aşa ne-a lăsat Dumnezeu, în „Tabor”, anul III, nr. 12, martie 2010, p. 41 
laudă cu istoria, cu limba lor, se întunecă dacă nu le vorbeşti pe limba lor, pe care, după cum cred ei, ar trebui să o cunoască toată lumea ${ }^{24}$.

Noi, s-ar cuveni să rămânem cu demnitatea strămoşilor, care nu şi-au vândut sufletul pentru un blid de linte, să ne obişnuim că viaţa înseamnă demnitate, corectitudine, strădanie, iar Biserica, Familia şi Şcoala sunt chemate în a deveni punctul arhimedic al neamului românesc.

\section{Bibliografie}

1. Branişte Ene, Branişte, Ecaterina, Dicţionar enciclopedic de cunoştinţe religioase, Caransebeş, Edit. Dicezană, 2001.

2. Buta, Mircea Gelu, Religie şi universitate în postmodernism, în „Tabor”, anul IV, nr. 4, iulie, 2010.

3. Crainic, Nichifor, Zile albe, zile negre", ediție îngrijită de Nedic Lemnaru, Bucureşti, Casa Editorială „Gândirea”, 1991.

4. Daniel, Patriarhul Bisericii Ortodoxe Române, Lumina educaţiei promovată in cooperarea dintre Biserică, Familie şi Şcoală, în „Vestitorul Ortodoxiei”, anul VIII (XXV), nr. 5-6 (503- 504), mai-iunie, 2015.

5. Furet, François, Le Passé d'une illusion. Essair sur l'idée communiste au XX-e siècle, Robert Laffont/ Calmann-Lévy (eds.), Paris, 1995, trad. în româneşte de E. Marcu, V. Russo, sub titlul: Trecutul unei iluzii. Eseu despre ideea comunistă in secolul XX, Bucureşti, Edit. Humanitas, 1996.

6. Gordon, Vasile, Nichifor Crainic - nume de cinste pentru o Antologie românească a pedagogilor laici ortodocşi, în „Tabor”, anul III, nr. 10, ianuarie, 2010.

7. Got, Mioriţa, Educaţia - o pasiune care se reînnoieşte, în „Viaţa creştină”, Cluj Napoca, anul XXVII, nr. 3 (445), 2016.

8. Marga, Andrei, Dialoguri, Cluj-Napoca, Presa Universitară Clujeană, 2008.

9. Millon-Delson, Chantal, Les Idées politiques au XX ème siècles, Presses Universitaires de France, Paris, 1991, trad. în româneşte de V. Boari, sub titlul: Ideile politice ale secolului XX, Iaşi, Edit. Polirom, 2002.

10. Opriş, Dorin, Dimensiuni creştine ale pedagogiei moderne, ediţia a III-a, Bucureşti, Edit. Didactică şi pedagogică R. A., 2012.

${ }^{24}$ Ibidem, p. 42 
11. Opriş, Dorin, Opriş, Monica, Religia şi educaţia de mâine. Cercetări pedagogice, Cluj-Napoca, Editura Eikon, 2013.

12. Pipes, Richard, Communism. A Brief History, London, Weidenfeld \& Nicholson, 2001.

13. Popescu, Teodor M., Biserica şi cultura, Bucureşti, Edit. Institutului Biblic şi de Misiune al Bisericii Ortodoxe Române, 1996.

14. Preda, Radu, Condamnarea comunismului. Dilema etică a Europei, în „Tabor”, anul III, nr. 7, octombrie, 2009.

15. Sfântul Ioan Gură de Aur, Cuvânt despre educaţia copiilor, Sibiu, Edit. Deisis, 2006,

16. Stăniloae, Dumitru, Reflecţii despre spiritualitatea poporului român, Bucureşti, Edit. Elion, 2002.

17. Stăniloae, Lidia, Aşa ne-a lăsat Dumnezeu, în „Tabor”, anul III, nr. 12, martie, 2010.

\section{Adrese web:}

http://www.czech.cz/de/publizistik/vorstellung-der-tschechischenrepublik/vaclav-havel-wir-stehen-am-beginn-schwerwiegender-veranderungen, (accesat la data de 15. 07. 2009).

http://www. ro.metapedia.org/wiki/Nichifor_Crainic (accesat la data de 15. 07. 2009). 